\title{
Pengaruh Kadar Suspensi Pati Kulit Pisang Kepok pada Kinetika Reaksi Proses Hidrolisis
}

\author{
$1^{*}$ Neneng Purnamawati, ${ }^{2}$ Arief Yandra Putra \\ ${ }^{1}$ Fakultas Teknik, ${ }^{2}$ Pendidikan Kimia FKIP Universitas Islam Riau \\ *Email: nenengpurnamawati@eng.uir.ac.id
}

\begin{abstract}
Abstrak
Kulit Pisang merupakan salah satu limbah yang dapat mencemari lingkungan sehingga perlu dimanfaatkan. Salah satu kandungan kulit pisang kepok adalah pati (karbohidrat). Pati kulit pisang dapat terkonversi menjadi glukosa dengan metode hidrolisis. Penelitian ini bertujuan untuk mencari pengaruh kadar suspensi pati kulit pisang pada kinetika reaksi proses hidrolisis tersebut. Proses Hidrolisis menggunakan asam oksalat $2 \mathrm{~N}$ dengan waktu reaksi berselang 10, 20, 30, 40 dan 50 menit serta kadar suspensi pati kulit pisang kepok (gr/mlcamp) adalah 10/250, 20/250 dan 30/250. Hasil penelitian menunjukan bahwa hasil optimum didapat pada kadar suspensi 10/250 gr/ml dengan konversi reaksi mencapai $35 \%$ pada waktu 50 menit suhu tetap $100^{\circ} \mathrm{C}$.
\end{abstract}

Kata kunci : Hidrolisi, Pisang Kepok, Kinetika Reaksi

\section{Abstract}

Banana peel is one of the wastes that can pollute the environment so it needs to be utilized. One of the ingredients in kepok banana peels is starch (carbohydrates). Banana peel starch can be converted into glucose by hydrolysis method. This study aimed to find out the effect of banana peel starch suspension levels on the reaction kinetics of the hydrolysis process. The hydrolysis process used $2 \mathrm{~N}$ oxalic acid with reaction times of 10,20,30, 40 and 50 minutes and the levels of suspension of kepok banana peel starch (gr/mlcamp) were 10/250, 20/250 and 30/250. The results showed that the optimum results were obtained at a suspension content of $10 / 250 \mathrm{gr} / \mathrm{ml}$ with a reaction conversion reaching $35 \%$ at a time of 50 minutes at a constant temperature of $100^{\circ} \mathrm{C}$.

Keywords : Hydrolysis, Banana Kepok, Reaction Kinetics

\section{Pendahuluan}

Pisang (Musaceaea SP) merupakan tanaman asli Asia Tenggara. Hampir diseluruh wilayah Indonesia terdapat tanaman pisang. Hal ini dikarenakan iklim Indonesia cocok untuk media tumbuh tanaman ini. Salah satu bagian dari tanaman pisang yang bisa dimanfaatkan adalah kulit buah pisang.

Berdasarkan hasil analisa kimia, komposisi kimia kulit pisang tertera dalam tabel 1.

Tabel 1. Komposisi kimia kulit pisang

\begin{tabular}{|c|c|c|}
\hline Unsur & Satuan & Jumlah \\
\hline Air & $(\%)$ & 66,9 \\
\hline Karbohidrat & $(\%)$ & 18,50 \\
\hline
\end{tabular}




\begin{tabular}{|c|c|c|}
\hline Lemak & $(\%)$ & 2,11 \\
\hline Protein & $(\%)$ & 0,32 \\
\hline Kalsium & $(\mathrm{mg} / 100 \mathrm{~g})$ & 715,00 \\
\hline Fosfor & $(\mathrm{mg} / 100 \mathrm{~g})$ & 117,00 \\
\hline Besi & $(\mathrm{mg} / 100 \mathrm{~g})$ & 1,60 \\
\hline Vitamin B & $(\mathrm{mg} / 100 \mathrm{~g})$ & 0,12 \\
\hline Viatmin C & $(\mathrm{mg} / 100 \mathrm{~g})$ & 17,50 \\
\hline
\end{tabular}

(Anna Poejiadi, 1994)

Berdasarkan tabel 1, maka dapat kita lihat bahwa selain air terdapat karbohidrat yang mempunyai komposisi $18,50 \%$ yang dapat dimanfaatkan untuk menghasilkan glukosa dengan menghidrolisis pati.

Amilum atau pati banyak terdapat dalam berbagai jenis tumbuh-tumbuhan dan disimpan dalam akar, batang buah, kulit, biji sebagai makanan cadangan. Pati berwujud putih bubuk seperti tepung.

Ditinjau dari rumus kimianya, pati merupakan karbohidrat berbentuk polisakarida berupa polimer anhidro monosakarida dengan rumus umum $\left(\mathrm{C}_{6} \mathrm{H}_{10} \mathrm{O}_{5}\right)$ n. Penyusun utama pati adalah amilosa dan amilopektin. Amilosa tersusun atas satuan glukosa yang saling berkaitan melalui ikatan 1-4 glukosida, sedangkan amilopektin merupakan polisakarida yang tersusun atas $1-4 \alpha$ glikosida dan mempunyai rantai cabang 1-6a glukosida (Kirk dan Othmer, 1954).

Hidrolisis adalah proses pemisahan yang melibatkan perpindahan ion $\mathrm{OH}^{-}$dan $\mathrm{H}^{+}$ dari $\mathrm{H}_{2} \mathrm{O}$ terhadap zat yang dihidrolisis. Hasil hidrolisis biasanya berupa senyawa yang bersifat asam apabila menerima ion $\mathrm{H}^{+}$dan bersifat basa bila menerima ion $\mathrm{OH}^{-}$.

Reaksi hidrolisis dapat dijalankan pada tekanan lebih dari satu atmosfir dan suhu lebih dari $100^{\circ} \mathrm{C}$ dalam autoklaf. Hal ini dimaksudkan agar campuran masih dalam fase cair, sehingga reaksi dapat berjalan lebih cepat. Adapun reaksi hidrolisis yang dijalankan pada suhu rendah dan tekanan satu atmosfir, dengan zat-zat yang dihidrolisis tidak banyak yang rusak. (Agra, 1973)

Faktor-faktor yang mempengaruhi proses hidrolisis adalah waktu reaksi dimana semakin lama waktu reaksi hidrolisis, makin besar pula konversi pati. Tetapi waktu yang 
terlalu lama akan mempengaruhi warna dan aroma hasil. Hal ini telah dibuktikan oleh Novy dkk., (2015) menunjukkan bahwa kadar glukosa tertinggi pada waktu 60 menit adalah pada temperatur $100^{\circ} \mathrm{C}$ dengan kadar glukosa yaitu $10,7 \mathrm{mg} / \mathrm{mL}$ pada rentang variasi 10-60 menit.

Faktor selanjutnya adalah suhu reaksi. Pada hidrolisis pati suhu tidak boleh terlalu tinggi, sebab konversi yang diperoleh akan menurun. Hal ini disebabkan adanya glokusa yang mengalami karamelisasi. Dan dibuktikan dari semakin tuanya warna hasil hidrolisis. (Agra, 1973)

Katalisator sangat mempengaruhi kinetika reaksi. Untuk hidrolisis pati, katalisator yang digunakan biasanya bersifat asam. Jenis asam yang dapat digunakan sebagai katalisator antara lain asam klorida, asam sulfat, asam nitrat dan asam oksalat. Untuk produk yang akan dipakai sebagai bahan makanan, sering digunakan asam oksalat. Hal ini disebabkan karena garam sisi yang terbentuk tidak berbahaya. (Agra, 1973)

Kecepatan reaksi akan bertambah dengan naiknya konsentrasi katalisator yang digunakan. Wicaksono (2008) melakukan penelitian pengaruh konsentrasi katalis $\left(\mathrm{H}_{2} \mathrm{SO}_{4}\right)$ terhadap reaksi hidrolisis polisakarida dari sampah kota (sayur dan buah). Dengan konsentrasi gula terbanyak dihasilkan pada konsentrasi katalis $1 \%$ dalam kisaran 0,25-1\% (volume).

Faktor yang berpengaruh selanjutnya pada proses hidrolisi pati adalah kadar suspensi. Pada kadar suspensi tinggi mengakibatkan kekentalan campuran akan semakin meningkat, sehingga tumbukan antara molekul-molekul pati dan air akan makin berkurang, dan reaksi berjalan lambat.

Pada kadar suspensi yang rendah reaksi akan lebih cepat. Hal ini disebabkan oleh makin bebasnya molekul pati, sehingga frekuensi tumbukan makin besar. Meskipun penambahan air akan memperbesar konversi, tetapi penambahan air yang berlebihan perlu dihindari, karena hasil yang terlalu encer akan meningkatkan waktu dan biaya pemekatan untuk mendapatkan hasil yang murni. (Groggins, 1958)

Dalam penelitian ini dilakukan berbagai variasi terkair kadar suspensi pada suhu tetap $100^{\circ} \mathrm{C}$, tekanan 1 atm dengan konsentrasi katalis berupa asam oksalat $2 \mathrm{~N}$ dengan volume larutan $250 \mathrm{ml}$ guna mendapatkan kecepatan reaksi yang optimum. 


\section{Metode}

\subsection{Alat dan Bahan}

Alat yang digunakan pada penelitian ini adalah labu leher tiga, mantel pemanas, termometer, oven, eksikator, alat titrasi dan blender. Bahan yang digunakan pada penelitian ini adalah kulit buah pisang kepok, Fehling A, Fehling B, Asam Oksalat, Larutan glukosa standar, $\mathrm{NaOH}$, Indikator Methylen biru.

\subsection{Persiapan Sampel}

Pada penelitian ini kita membuat tepung pisang. Kulit pisang dibersihkan, lalu dipotong-potong dan direbus selama beberapa menit. Selesai perebusan, bahan dijemur sampai kering (dapat menggunakan oven pengering dengan suhu $80^{\circ} \mathrm{C}$ selama 36 jam). Setelah kering diblender dan diayak dengan menggunakan ayakan 200 mesh, selain untuk mendapatkan tepung kulit pisang yang halus, ayakan tipe ini mudah didapatkan dipasaran.

\subsection{Proses Hidrolisis}

Proses hidrolisis dilakukan pada labu leher tiga yang dilengkapi dengan jaket pemanas dan pendingin balik, dimana tepung pati kulit pisang (10, 20 dan 30 gram) dicampur dengan $20 \mathrm{ml}$ asam oksalat $2 \mathrm{~N}$, lalu ditambahkan akuades sampai volume $250 \mathrm{ml}$ dipanaskan sampai suhu $100^{\circ} \mathrm{C}$, tekanan $1 \mathrm{~atm}$. Hidrolisis dilakukan selama 10 , 20, 30, 40 dan 50 menit.

\subsection{Analisis Data}

Analisa sampel terdiri dari analisa kadar air dan kadar pati pada tepung kulit pisang. Sementara untuk analisa hasil penelitian dilakukan dengan cara mengambil sampel setiap selang waktu 10 menit dan dititrasi, lalu dihitung volume titrasi guna mendapatkan data-data kinetika reaksi.

\section{Hasil dan Pembahasan}

Sebelum dilakukan proses hidrolisis, bahan baku dalam hal ini tepung kulit pisang dianalisa kadar air dan kadar patinya. Menghitung kadar air dilakukan dengan cara 
tepung kulit pisang 2 gram ditimbang dan dimasukkan ke dalam krus yang sudah diketahui beratnya. Kemudian dikeringkan dalam oven pada suhu $100^{\circ} \mathrm{C}$ sampai $105^{\circ} \mathrm{C}$ selama \pm 2 jam lalu didinginkan dalam deksikator sampai suhu kamar dan ditimbang kembali.

Kemudian dihitung dengan rumus :

$$
\text { Kadar }=\frac{\text { gr basah }- \text { gr kering }}{\text { gr basah }} \times 100 \%
$$

Sehingga didapatkan hasil kadar air sampel adalah 10\%. Kadar air ini memenuhi syarat standar kadar air dalam pati SNI 3451 (2011) yaitu maksimal 14\%.

Sedangkan untuk menghitung kadar pati dilakukan dengan cara tepung kulit pisang ditimbang sebanyak 4 gram dan dimasukkan ke dalam labu leher tiga dengan menambahkan $200 \mathrm{ml}$ akuades dan $20 \mathrm{ml}$ asam oksalat $2 \mathrm{~N}$. Kemudian panaskan sampai mendidih atau suhu konstan \pm 2 jam. Untuk menjaga suhu tetap konstan, rangkaian alat hidrolisis dilengkapi dengan pendingin balik.

Setelah mencapai suhu $25^{\circ} \mathrm{C}$ dinetralkan dengan $\mathrm{NaOH} 2 \mathrm{~N}$ dan diencerkan sampai volume $500 \mathrm{ml}$, kemudian disaring dan didapatkan filtrat yang sudah bebas asam.

Kemudian diambil $5 \mathrm{ml}$ filtrat yang ditambahkan $5 \mathrm{ml}$ Fehling $A$ dan $5 \mathrm{ml}$ Fehling $B$ dimasukkan ke dalam erlenmeyer. Panaskan sampai mendidih dan tambahkan 3 tetes indikator methylen biru dan titrasi dengan larutan glukosa standar sampai terjadi perubahan warna merah bata.

Dengan menggunakan persamaan

$$
\begin{gathered}
C=\frac{V 1}{V 2} \times \text { CoxVo } \\
\text { KadarPati }=\frac{0,9 C}{W}
\end{gathered}
$$

Dimana :

$V_{O}=$ Volume larutan glukosa standar yang digunakan untuk titrasi fehling $A$ dan fehling $\mathrm{B}, \mathrm{ml}$

$\mathrm{V}_{1}=$ Volume pengenceran hasil hidrolisis, $\mathrm{ml}$

$\mathrm{V}_{2}=$ Volume larutan hasil hidrolisis yang telah diencerkan yang digunakan untuk titrasi fehling $A$ dan fehling $B, m l$

$\mathrm{Co}=$ Kadar larutan glukosa standar, $\mathrm{g} / \mathrm{ml}$ 
$\mathrm{C}=$ Jumlah glukosa total hasil hidrolisis, gr

$\mathrm{W}=$ Berat sampel, gr

didapatkan kadar pati dalam tepung kulit pisang sampel sebesar 0,8865.

Untuk menganalisa pengaruh kadar suspensi pati pada kinetika reaksi dilakukan dengan memvariasikan bahan baku 10, 20, 30 gram dalam volume larutan $250 \mathrm{ml}$, kemudian dipanaskan sampai suhu konstan $100^{\circ} \mathrm{C}$. larutan tersebut diambil untuk dititrasi dengan selang waktu 10 menit. Analisa hasil menggunakan persamaan Lane and Eynon (Woodman, 1945),

$$
X=\frac{\frac{V m}{V c} x \frac{V v}{V s} x\left(V_{1}-V_{2}\right) \times G \times 0,9}{m \times k} \times 100 \%
$$

Dimana :

$$
\begin{aligned}
\mathrm{X}= & \text { konversi } \\
\mathrm{Vm}= & \text { volume larutan mula-mula, } \mathrm{ml} \\
\mathrm{V}_{\mathrm{C}=}= & \text { volume larutan hasil encer, } \mathrm{ml} \\
\mathrm{V} \mathrm{V}= & \text { volume pengenceran, } \mathrm{ml} \\
\mathrm{G}= & \text { kadar glukosa standar, } \mathrm{g} / \mathrm{ml} \\
\mathrm{V}_{1}= & \text { volume glukosa standar untuk } \\
& \text { mentitrasi Fehling, } \mathrm{ml} \\
\mathrm{V}_{2}= & \text { volume glukosa standar untuk } \\
& \text { mentitrasi sampel dan Fehling } \\
\mathrm{m}= & \text { berat bahan, gram } \\
\mathrm{k}= & \text { kadar pati }
\end{aligned}
$$

Tabel 2. Hasil Pengamatan Hidrolisis kadar suspensi pati terhadap konversi

\begin{tabular}{c|c|c|c}
\hline \multirow{2}{*}{$\begin{array}{c}\text { Waktu } \\
\text { (menit) }\end{array}$} & \multicolumn{3}{|c}{$\begin{array}{r}\text { Konversi, X pada kadar } \\
\text { suspensi pati (gr/ml) }\end{array}$} \\
\cline { 2 - 4 } & $10 / 250$ & $20 / 250$ & $30 / 250$ \\
\hline 10 & 0,0761 & 0,0507 & 0,0423 \\
\hline 20 & 0,1649 & 0,1459 & 0,1184 \\
\hline 30 & 0,2284 & 0,2093 & 0,1819 \\
\hline
\end{tabular}




\begin{tabular}{c|l|l|l}
\hline 40 & 0,2919 & 0,2728 & 0,2242 \\
\hline 50 & 0,3553 & 0,3363 & 0,3088 \\
\hline
\end{tabular}

Hubungan antara konversi terhadap waktu reaksi pada kadar suspensi tertentu dapat dilihat pada gambar 1.

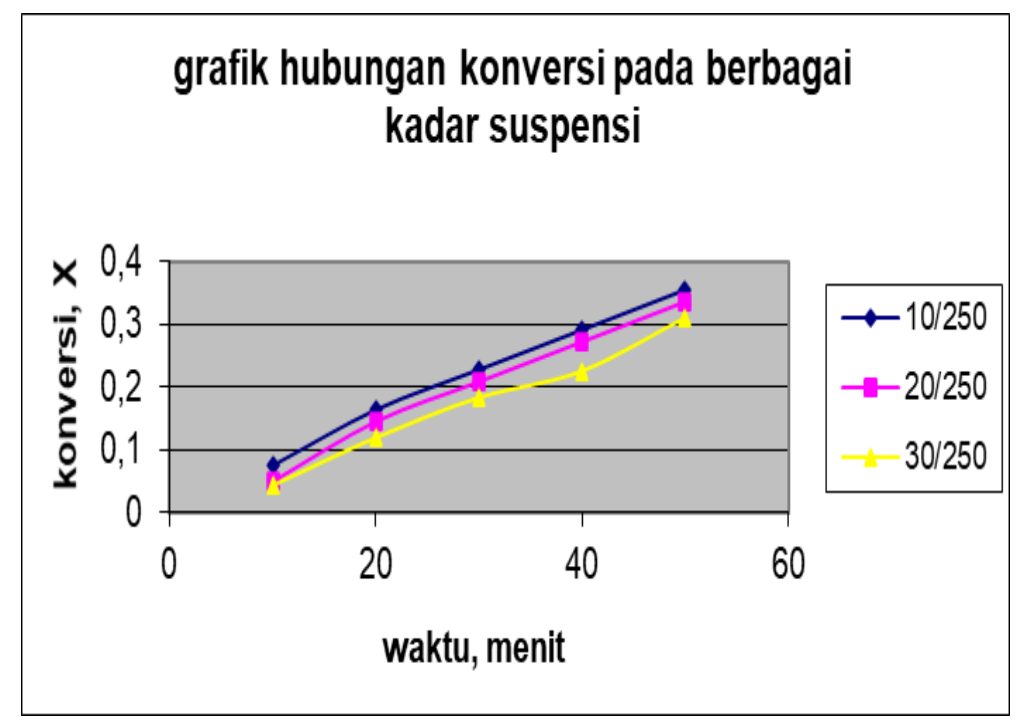

Gambar 1. Grafik hubungan antara waktu dan konversi pada tiap kadar suspensi

Pada penelitian pengaruh kadar suspensi, peubah yang dipertahankan tetap adalah suhu dan konsentrasi katalisator. Dari tabel 2 terlihat bahwa semakin lama waktu reaksi, maka semakin besar nilai konversi. Hal ini disebabkan kesempatan saling bertumbukan antara molekul-molekul pati dan air semakin lama.

Sedangkan dengan penggunaan kadar suspensi yang makin tinggi, maka konversi makin menurun. Dengan kadar suspensi 10/250 gr/mlcamp dan waktu hidrolisis 50 menit, nilai konversi adalah 0,3553. Sebaliknya pada pemakaian kadar suspensi 30/250 $\mathrm{gr} / \mathrm{mlcamp}$ dan waktu hidrolisis 50 menit, nilai konversi yang diperoleh adalah 0,3088.

Hasil ini sesuai dengan analisa terhadap faktor yang mempengaruhi proses hidrolisis pati. Pada kadar suspensi yang rendah reaksi akan lebih cepat. Hal ini disebabkan oleh makin bebasnya molekul pati, sehingga frekuensi tumbukan makin besar. Meskipun penambahan air akan memperbesar konversi, tetapi penambahan air 
yang berlebihan perlu dihindari, karena hasil yang terlalu encer akan meningkatkan waktu dan biaya pemekatan untuk mendapatkan hasil yang murni. (Groggins, 1958)

Sementara hasil pengamatan pengaruh kadar suspensi pati terhadap konstanta kecepatan reaksi terlihat pada tabel 3 .

Tabel 3. Pengaruh kadar suspensi terhadap harga konstanta kecepatan reaksi

\begin{tabular}{c|c|c|c}
\hline $\begin{array}{c}\text { Waktu } \\
\text { menit }\end{array}$ & \multicolumn{3}{|c}{$\begin{array}{c}\text {-In (1-X) pada berbagai } \\
\text { kadar suspensi }\end{array}$} \\
\hline & $10 / 250$ & $20 / 250$ & $30 / 250$ \\
10 & 0,0792 & 0,0520 & 0,0432 \\
20 & 0,1802 & 0,1577 & 0,1260 \\
30 & 0,2593 & 0,2348 & 0,2008 \\
40 & 0,3452 & 0,3186 & 0,2539 \\
50 & 0,4389 & 0,4099 & 0,3693 \\
\hline $\mathrm{k}\left(10^{-3}\right)$ & 6,854 & 6,681 & 6,388 \\
\hline
\end{tabular}

Dari table 3 dapat dilihat bahwa semakin besar kadar suspensi yang dalam hal ini dapat kita anggap sebagai konsentrasi suatu zat dengan lambang $C_{A}$, maka semakin kecil nilai konsentrasi kecepatan reaksinya. Sehingga kecepatan reaksi juga akan menurun.

Menurunnya konstanta kecepatan reaksi tersebut karena kekentalan campuran semakin meningkat, sehingga dapat menghalangi kecepatan molekul untuk saling bertumbukan, maka reaksi berjalan lambat.( Levenspiel, 1972)

Dari table tiga dapat dicari orde reaksi dengan membandingkan waktu reaksi dengan $-\ln (1-X)$, seperti yang terlihat pada grafik 2 .




Gambar 2. Grafik hubungan antara waktu reaksi dengan -In (1-X)

Konsentrasi katalisator dianggap tetap selama pati bereaksi, sehingga kecepatan reaksi hanya tergantung pada konsentrasi pati. Dengan demikian dapat ditulis

$$
\begin{aligned}
& (-r A)=\frac{-d C_{A}}{d t}=k C_{A}{ }^{n} \\
& (-r A)=\frac{-d C_{A}}{d t}=k C_{A}
\end{aligned}
$$

Jika $\mathrm{n}=1$, maka

$$
C_{A}=C_{A O}\left(1-X_{A}\right)
$$

Dimana : $(-\mathrm{rA})=$ kecepatan reaksi

$$
\mathrm{C}_{\mathrm{A}}=\text { konsentrasi } \mathrm{A} \text { setiap saat }
$$

$\mathrm{C}_{\mathrm{AO}}=$ konsentrasi $\mathrm{A}$ mula-mula

$\mathrm{X}_{\mathrm{A}}=$ konversi

$\mathrm{k}=$ konst. kecepatan reaksi

Maka :

$$
(-r A)=\frac{-d C_{A}\left(1-X_{A}\right)}{d t}=k C_{A}\left(1-X_{A}\right) \quad-\int \frac{d\left(1-X_{A}\right)}{\left(1-X_{A}\right)}=\int k d t
$$

Setelah diintegralkan didapatkan persamaan :

$$
\operatorname{Ln}\left(1-X_{A}\right)=k t+C
$$

Dimana: $\quad t=$ waktu reaksi

$$
\mathrm{C}=\text { suatu konstanta }
$$

Dari persamaan tersebut diatas, jika dibuat grafik yang menyatakan hubungan antara In $\left(1-X_{A}\right)$ dengan $t$ berupa garis lurus, berarti reaksi mengikuti orde satu.

Pada hidrolisis pati ada kemungkinan reaksi mengikuti orde dua di tinjau dari konsentrasi pati.

$$
(-r A)=\frac{-d C_{A}}{d t}=k C_{A}{ }^{n}
$$


Jika $\mathrm{n}=2$, maka :

$$
\begin{gathered}
(-r A)=\frac{-d C_{A}}{d t}=k C_{A}{ }^{n} \\
-\int_{0}^{X A} \frac{d\left(1-X_{A}\right)}{\left(1-X_{A}\right)}=\int_{0}^{t} k C_{A O} d t \\
-\frac{C_{A O} d\left(1-X_{A}\right)}{d t}=k\left(C_{A O}\left(1-X_{A}\right)\right)^{2} \\
-\frac{C_{A O} d\left(1-X_{A}\right)}{d t}=k C_{A O} O^{2}\left(1-X_{A}\right)^{2} \\
-\frac{d\left(1-X_{A}\right)}{\left(1-X_{A}\right)^{2}}=k C_{A O} d t
\end{gathered}
$$

Setelah diintegralkan diperoleh persamaan (Levenspiel, 1972)

$$
\frac{X_{A}}{\left(1-X_{A}\right)}=k C_{A O} t
$$

Dari persamaan diatas, jika dibuat grafik menyatakan hubungan antara $X_{A} /\left(1-X_{A}\right)$ dengan $t$ berupa garis lurus, berarti reaksi mengikuti orde dua dengan tangen arah $\mathrm{kC}_{\mathrm{AO}}$. (Agra, 1992)

Bila kita amati grafik hubungan antara waktu reaksi dengan - In (1-X) mengikuti reaksi tingkat satu. Karena hubungan antara $-\operatorname{In}(1-X)$ dan waktu berupa garis lurus.

\section{Kesimpulan}

Konstanta kecepatan reaksi paling optimum untuk kondisi hidrolisis pati pada suhu $100^{\circ} \mathrm{C}$, tekanan $1 \mathrm{~atm}$ dan kadar katalis $20 \mathrm{ml}$ asam oksalat $2 \mathrm{~N}$ adalah pada kadar suspensi $10 / 250 \mathrm{gr} / \mathrm{mlcamp}$ yaitu $6,845 \times 10^{-3}$ karena merupakan reaksi paling cepat dengan lama waktu reaksi adalah 50 menit. Orde atau tingkat reaksi pada kondisi tersebut mengikuti reaksi tingkat satu.

\section{Daftar Referensi}

Agra; Ida Bagus; Sri Warnijati; dan Pudjianto., 1973, Hidrolisis Pati Ketela Rambat Pada Suhu Lebih dari $100^{\circ} \mathrm{C}$, Forum Teknik, Jilid 3, No. 3, 115-29. 
Agatha Permatasari Mayang; Reni Puspita Sari; Rif'an Fathoni., 2019, Pembuatan Glukosa Dari Kulit Pisang Kepok (Musa Paradisiaca L.) Dengan Proses Hidrolisis, Jurnal Integrasi Proses, UNTIRTA, vol.8, no.1, 39-44.

Anna Poejiadi., 1994, Dasar-dasar Biokimia, Penerbit Universitas Indonesia (UI-Press), Jakarta.

Groggins, P.H., 1958, Unit Process in Organic Synthesis, Mc Graw Hill Book Company, New York.

Jatmiko, W.; Wusana, A.W.; Yulian, A.R.; Atika, K., 2011,Pengaruh Suhu Terhadap Kadar Glukosa Terbentuk Dan Konstanta Kecepatan Reaksi PadaHidrolisis Kulit Pisang. Pengembangan Teknologi Kimia untuk Pengolahan Sumber Daya Alam Indonesia,Yogyakarta.

Kirk, R.E.; Othmer,D.F., 1951, Encyclopedia of Chemical Technology Interscience Incyclopedia Inc, New York, vol. 5, hal.781-790.

Levenspiel, O., 1972, Chemical Reaction Engineering2nd, John Willey and Sons, New York.

Novy, S.; Meriatna, H., 2010, Kinetika Kulit Pisang Kepok Menjadi Glukosa menggunakan Katalis Asam Klorida, Jurnal Teknologi Kimia Unimal 4, 51-65.

Syamsiah, S., 1987, Hidrolisis Bonggol Pisang Menjadi Glukosa, Program Pasca Sarjana, Universitas Gadjah Mada, Yogyakarta.

Wicaksono, D.R., 2008, Pengaruh Konsentrasi Katalis $\mathrm{H}_{2} \mathrm{SO}_{4}$ Terhadap Reaksi Hidrolisis Polisakarida Dari Sampah Kota (Sayur dan Buah), Info-Teknik, vol.9, 3135. 